\title{
Kuersetin dari Daun Erythrina poeppigiana (leguminosae)
}

\author{
Tati Herlina*) dan Unang Supratman
}

\begin{abstract}
Departemen Kimia, Fakultas Matematika dan Ilmu Pengetahuan Alam Universitas Padjadjaran, Jl. Raya BandungSumedang Km 21 Jatinangor 45363
\end{abstract}

Diterima 03-11-2016 disetujui 13-02-2017

\begin{abstract}
Erythrina plants known plants "dadap" is a higher plant that grows in tropical and subtropical regions. E. poeppigiana plants was a source of secondary metabolites, which contain flavonoids. This study aims to isolate the flavonoid compounds from the leaves of E. poeppigiana through the stages of extraction, fractionation, separation and purification. E. poeppigiana leaves powder $(2.5 \mathrm{~kg})$ was extracted with methanol and partitioned with n-hexane and ethyl acetate. Furthermore, the separation of ethyl acetate of E. poeppigiana leaves fraction using a combination of column chromatographic was obtained pure compound $(5 \mathrm{mg})$ in the form of a yellow amorphous solid. The chemical structure of pure compound was based on the data spectroscopy (MS, UV, IR, 1H-NMR and 13C-NMR) and identified as the compound 3,3 ', 4', 5,7-pentahidroksiflavon or known as quercetin.
\end{abstract}

Keywords: Erythrina poeppigiana, flavonoid, quercetin

\begin{abstract}
ABSTRAK
Tumbuhan Erythrina dikenal dengan tumbuhan "dadap" merupakan tumbuhan tinggi yang tumbuh di daerah tropis dan subtropis. Tumbuhan E. poeppigiana merupakan sumber senyawa metabolit sekunder yang mengandung flavonoid. Penelitian ini bertujuan untuk mengisolasi senyawa flavonoid dari daun E. poeppigiana melalui tahapan ekstraksi, fraksionasi, pemisahan dan pemurnian. Serbuk daun E. poeppigiana $(2,5 \mathrm{~kg})$ diekstraksi dengan pelarut metanol dan dipartisi dengan $n$-heksana dan etil asetat. Selanjutnya dilakukan pemisahan fraksi etil asetat daun E. peoppigiana menggunakan kombinasi kromatografi kolom diperoleh senyawa murni $(5 \mathrm{mg})$ berupa padatan amorf kuning. Struktur kimia senyawa murni ditetapkan berdasarkan data-data spektroskopi (MS, UV, IR, 1H-NMR dan 13C-NMR) dan diidentifikasikan sebagai senyawa 3,3',4',5,7pentahidroksiflavon atau lebih dikenal dengan kuersetin.
\end{abstract}

Kata kunci: Erythrina poeppigiana, flavonoid, kuersetin

\section{PENDAHULUAN}

Indonesia merupakan salah satu negara yang memiliki wilayah hutan tropis dengan keanekaragaman hayati tertinggi ke-2 di dunia setelah Brazil. Sebanyak 40.000 jenis flora yang ada di dunia, 30.000 jenis diantaranya dapat dijumpai di Indonesia (Masyhud 2010). Keanekaragaman hayati ini telah dimanfaatkan oleh masyarakat untuk berbagai keperluan antara lain sebagai bahan baku industri,

*Telp: +628121408616

Email: tati.herlina@unpad.ac.id bahan pangan, pertanian dan obat-obatan. Banyak jenis tumbuhan yang sudah dimanfaatkan sejak lama sebagai obat tradisional, namun masih banyak senyawa metabolit sekunder yang terkandung di dalamnya yang belum diketahui (Hasnirwan et al. 2013).

Salah satu tumbuhan yang diketahui memiliki banyak kandungan senyawa flavonoid adalah tumbuhan $E$. poeppigiana. Tumbuhan E. poeppigiana merupakan salah satu spesies dari genus Erythrina keluarga Leguminosae 
yang sangat berpotensi sebagai sumber senyawa metabolit sekunder. Tumbuhan ini banyak tersebar luas di negaranegara tropis (Hussain et al. 2016). Hikita et al. (2014), melaporkan senyawa isoflavon, erythgianin dan isolupalbigenin dari kulit batang E. poeppigiana. Senyawa isolupalbigenin menunjukkan aktivitas sitotoksik terhadap sel leukemia HL-60 (Hikita et al. 2015). Senyawa isopoegin $\mathrm{A}$, isopoegin $\mathrm{B}$, isopoegin $\mathrm{C}$ dan isopoegin $\mathrm{D}$ dari kulit batang E. poeppigiana (Djiogue et al. 2009). Senyawa alkaloid eritrina golongan isokuinolin, 6,7-dihidro-17hidroksierisotrin diperoleh dari daun E. poeppigiana menunjukkan aktivitas sitotoksik terhadap sel kanker payudara MCF-7 secara in silico (Mardianingrum et al. 2015).

Berdasarkan penelitian sebelumnya, dilakukan penelitian lebih lanjut terhadap daun E. poeppigiana untuk mengetahui senyawa flavonoid yang terkandung di dalam daun E. poeppigiana.

\section{BAHAN DAN METODE}

Bahan tumbuhan yang digunakan dalam penelitian ini adalah bagian daun tumbuhan E. poeppigiana yang dikumpulkan dari Subang, Jawa Barat pada bulan Maret 2016 dan telah dideterminasi di Laboratorium Taksonomi Departemen Biologi UNPAD.

Peralatan yang digunakan dalam penelitian meliputi alat-alat gelas yang umum digunakan di laboratorium kimia organik, maserator, rotary evaporator R-200 Buchi dengan pompa vakum Vac V-500 Buchi dan penangas air B-490 Buchi, kolom kromatografi terbuka berbagai ukuran, spektrofotometer FTIR Shimadzu IR Prestige-2, Spektrofotometer Ultraviolet Hitachi model U-3210, Spektrometer massa TOF-ES-MS Waters, dan spektrometer Nuclear Magnetic Resonance (NMR) JEOL JNM ECA500.

Pemisahan dan Pemurnian. Serbuk daun kering $E$. poeppigiana $(2,5 \mathrm{~kg})$ diekstraksi dengan menggunakan metode maserasi dalam pelarut metanol selama $2 \times 24$ jam, diperoleh ekstrak pekat metanol (183,4 g). Selanjutnya ekstrak pekat metanol dilakukan partisi dengan menggunakan $n$-heksana dan etil asetat, diperoleh ekstrak pekat $n$-heksana (45,6 g) dan etil asetat $(3,5 \mathrm{~g})$.
Fraksi etil asetat $(3,5 \mathrm{~g})$ dipisahkan menggunakan metode kromatografi kolom dengan pelarut $n$ heksana:aseton (7:3 sampai 4:6) secara gradien, diperoleh delapan fraksi gabungan (F1-8). Fraksi F3 menunjukkan noda yang berpendar pada UV $\lambda 254 \mathrm{~nm}$ dan berpendar pada $\lambda 365 \mathrm{~nm}$ yang merupakan ciri dari senyawa flavonoid. Fraksi F3 (0,1778 g) dipisahkan dengan menggunakan metode kromatografi kolom menggunakan fasa diam silika gel G60 (70-230 mesh) yang dielusi dengan pelarut isokratik klorofom:etil asetat (9:1), diperoleh enam fraksi gabungan yaitu F3A-F. Fraksi 3D menunjukkan padatan amorf berwarna kuning sebanyak $5 \mathrm{mg}$. Untuk menguji kemurnian dari isolat F3D dilakukan teknik kromatografi lapis tipis pada pelat ODS yang dielusi dengan pelarut metanol:air (1:1) dan pada pelat silika menggunakan pelarut $n$ heksana:etil asetat (1:1) dan pelarut metilen klorida:etil asetat (7:3), yang masing-masing menunjukkan noda tunggal.

\section{HASIL DAN PEMBAHASAN}

Spektrum massa senyawa F3D memiliki massa atom relatif sebesar 302,0124; berdasarkan spektrum MS, 13CNMR dan 1H-NMR diduga mempunyai rumus molekul C15H10O7 dengan DBE (double bond equivalent) 11 yang memiliki 2 buah cincin benzen, 1 buah siklik, 1 ikatan rangkap dan 1 karbonil $(\mathrm{C}=\mathrm{O})$ yang merupakan kerangka dasar dari senyawa flavonoid.

Spektrum Ultraviolet senyawa F3D (pelarut metanol) dengan penambahan natrium hidroksida menyebabkan terjadinya pergeseran batokromik pada pita II yaitu dari 255-320 nm dan pada pita I yaitu dari 340,6-360,4 nm, hal ini menunjukkan bahwa adanya gugus $\mathrm{OH}$ bebas pada $\mathrm{C}$ 4' (Hasnirwan et al. 2013). Spektrum Inframerah senyawa $\mathrm{F} 3 \mathrm{D}$ (dalam $\mathrm{KBr}$ ) mengandung gugus $\mathrm{OH}$ yang ditunjukkan pada bilangan gelombang $3410 \mathrm{~cm}^{-1}$. Serapan pada bilangan gelombang $1610 \mathrm{~cm}^{-1}$ menunjukkan adanya gugus karbonil $(\mathrm{C}=\mathrm{O})$. Serapan pada bilangan gelombang $1494,7 \mathrm{~cm}^{-1}$ menunjukkan gugus C-C sp2. Serapan khas pada daerah sidik jari pada bilangan gelombang $1077,7 \mathrm{~cm}^{-1}$ menunjukkan adanya gugus fungsi $\mathrm{C}-\mathrm{O}$, dan serapan pada panjang gelombang $828,3 \mathrm{~cm}^{-1}$ menunjukkan adanya disubstitusi benzen. 
Spektrum 13C-NMR senyawa F3D (125 MHz dalam aseton- $d 6$ ) menunjukkan 15 sinyal karbon yang terdiri dari empat belas atom karbon aromatik benzen pada serapan

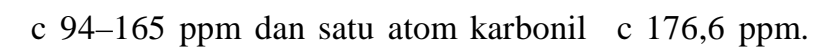
Adanya tujuh karbon oksiaril (O-CH $s p 2$ aromatik) pada ¿c 136,8; 145,9; 147,0; 148,4; 157,7; 162,3 dan 165,1 ppm; dan dua karbon aromatik yang shielded yang muncul pada sinyal $\delta \mathrm{c} 94,5$ dan 99,2 ppm yang khas merupakan kerangka flavonoid.

Spektrum 1H-NMR senyawa F3D (500 MHz dalam aseton- $d 6$ ) memiliki sepuluh proton yang terdiri dari lima proton dari C $s p 2$ (=CH-) $\delta \mathrm{H} 6,27 ; 6,53 ; 6,97 ; 7,70$ dan 7,80 ppm dan lima proton dari hidroksil $(\mathrm{OH})$ pada $8 \mathrm{H} \mathrm{12,17}$ ppm. Proton pada $\delta H ~ 6,27(1 \mathrm{H} ; \mathrm{d} ; 1,45)$ dan $\delta \mathrm{H} 6,53(1 \mathrm{H} ; \mathrm{d}$; 1,45) menunjukkan posisi dari proton ini adalah meta satu sama lain pada cincin A. Proton pada $\delta H ~ 7,70(1 \mathrm{H} ; \mathrm{d} ; 8,8)$ dan $\delta \mathrm{H} 6,97(1 \mathrm{H} ; \mathrm{d} ; 8,8)$ menunjukkan bahwa posisi orto satu dengan yang lainnya pada cincin B.

Untuk lebih meyakinkan dugaan struktur senyawa F3D, maka dilakukan perbandingan data dengan struktur senyawa yang mirip dengan senyawa $3,3^{\prime}, 4^{\prime}, 5,7-$ pentahidroksiflavon (Gambar 1). Perbandingan data 13CNMR dan 1H- NMR antara senyawa F3D dan senyawa 3,3',4',5,7-pentahidroksiflavon dapat dilihat pada Tabel 1, senyawa F3D teridentifikasi sebagai senyawa 3,3',4',5,7pentahidroksiflavon yang dikenal dengan kuersetin (Li $e t$ al. 2013).

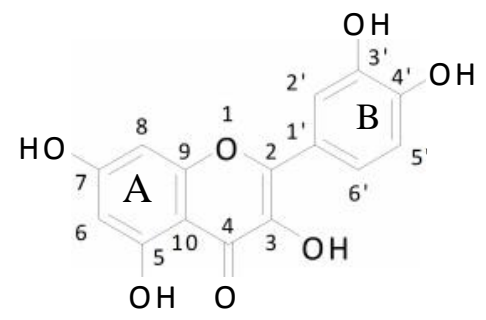

Gambar 1 Struktur kimia senyawa F3D

Senyawa kuersetin diketahui mempunyai sifat farmakologi sebagai pengobatan aterosklerosis, kolesterol, diabetes, katarak, demam, inflammasi, asma, dan pencegahan kanker (Golmaz et al. 2015)

Tabel 1 Perbandingan data 13C-NMR dan 1H-NMR senyawa F3D dengan kuersetin (Li et al. 2013)

\begin{tabular}{|c|c|c|c|c|}
\hline Posisi ke & F3D & Kuersetin & F3D & Kuersetina \\
\hline & $\delta \mathrm{C}(\mathrm{ppm})$ & $\delta \mathrm{C}(\mathrm{ppm})$ & $\delta \mathrm{H}$ (Int.; mult.; $J=\mathrm{Hz}$ ) & $\delta \mathrm{H}$ (Int.; mult.; $J=\mathrm{Hz}$ ) \\
\hline 1 & - & - & - & - \\
\hline 2 & 157,7 & 157,9 & - & - \\
\hline 3 & 136,8 & 136,9 & - & - \\
\hline 4 & 176,6 & 176,7 & - & - \\
\hline 5 & 162,3 & 162,5 & - & - \\
\hline 6 & 99,1 & 99,3 & $6,27(1 \mathrm{H} ; \mathrm{d} ; 1,45)$ & $6,25(1 \mathrm{H} ; \mathrm{d} ; 1,6)$ \\
\hline 7 & 165,1 & 165,1 & - & - \\
\hline 8 & 94,4 & 94,6 & $6,53(1 \mathrm{H} ; \mathrm{d} ; 1,45)$ & $6,51(1 \mathrm{H} ; \mathrm{d} ; 1,6)$ \\
\hline 9 & 148,4 & 148,5 & - & - \\
\hline 10 & 104,3 & 104,3 & - & - \\
\hline $1^{\prime}$ & 121,4 & 121,6 & - & - \\
\hline $2^{\prime}$ & 116,2 & 116,3 & $7,80(1 \mathrm{H} ; \mathrm{d} ; 8,8)$ & $7,81(1 \mathrm{H} ; \mathrm{d} ; 8,8)$ \\
\hline $3^{\prime}$ & 145,9 & 146,0 & - & - \\
\hline $4^{\prime}$ & 147,0 & 147,1 & - & - \\
\hline $5^{\prime}$ & 115,7 & 115,9 & $6,97(1 \mathrm{H} ; \mathrm{d} ; 8,8)$ & $6,99(1 \mathrm{H} ; \mathrm{d} ; 8,8)$ \\
\hline $6^{\prime}$ & 124,0 & 123,9 & $7,70(1 \mathrm{H} ; \mathrm{d} ; 8,8)$ & $7,70(1 \mathrm{H} ; \mathrm{dd} ; 8,8 ; 2,4)$ \\
\hline $5-\mathrm{OH}$ & - & & $12,17(1 \mathrm{H}, \mathrm{s})$ & $12,16(1 \mathrm{H}, \mathrm{s})$ \\
\hline
\end{tabular}




\section{SIMPULAN}

Senyawa flavonoid berupa padatan amorf berwarna kuning sebanyak $5 \mathrm{mg}$ berhasil diisolasi dari daun $E$. poeppigiana $(2,5 \mathrm{~kg})$. Senyawa flavonoid teridentifikasi sebagai senyawa 3,3',4',5,7-pentahidroksiflavon atau dikenal sebagai kuersetin dengan rumus molekul $\mathrm{C}_{15} \mathrm{H}_{10} \mathrm{O}_{7}$.

\section{UCAPAN TERIMA KASIH}

Penulis mengucapkan terima kasih kepada Lembaga Ilmu Pengetahuan dan Penelitian (LIPI) Serpong atas bantuan analisis NMR, Kementrian Riset, Teknologi dan Pendidikan Tinggi melalui dana Hibah Kompetensi Tahun Anggaran 2016.

\section{DAFTAR PUSTAKA}

Djiogue, S., Halabalaki, M., Alexi, X., Njamen, D., Fomum, Z.T., Alexis, M.N \& Skaltsounis, A.L. 2009. Isoflavonoids from Erythrina poeppigiana : evaluation of their binding affinity for the estrogen receptor. J Nat Prod 72(9): 1603-1607.

Golmaz, J.G., Quintremil, S \& Rodrigo, R. 2015. Cardiovascular Disease: A Target for the Pharmacological effects of Quercetin. Curr. Top Med Chem 15(17): 1735-1742.

Hasnirwan, Ibrahim, S \& Yanti, M. 2013. Isolasi dan karakterisasi flavonoid pada fraksi aktif antioksidan dari daging buah mahkota dewa (Phaleria macrocarpa (Scheff) Boerl). Open Journal System, Prosiding Semirata FMIPA Universitas Lampung 1(1): 1-6.
Hikita, K., Tanaka, H., Murata, T., Kato, K., Hirata, Miyuki., Sakai, T \& Kaneda, N. 2014. Phenolic constituents from stem bark of Erythrina poeoppigiana and their inhibitory activity on human glyoxalase I. Journal of Natural Medicines 68(3): 636642.

Hikita, K., Yamada, S., Shibata, R., Katoh, M., Murata, T., Tanaka, H \& Kaneda, N. 2015. Inhibitory Effect of Isoflavones from Erythrina poeppigiana on the Growth of HL-60 Human Leukemia Cells through Inhibition of Glyoxalase I. Nat. Prod. Commun 10(9): 1581-1584.

Hussain, M.M., Tuhin, M.T.H., Akter, F \& Rashid, M.A. 2016. Constituents of Erythrina-a Potential Source of Secondary Metabolites: A Review. Bangladesh Pharmaceutical Journal 19(2): 237-253.

Li, F.Y., Wei, H.Y., Chi, I.C., Sin, J.L \& Chih, C.H. 2013. Concurrent accumulation of myrecetin and gallic acid putatively responsible for the umami taste of a specialized old long tea. Journal of food and nutrition research 1(6): 164-173.

Mardianingrum, R., Herlina, T \& Supratman, U. 2015. Isolasi dan Molecular docking senyawa 6,7-dihidro17-hidroksierisotrin dari daun dadap belendung (Erythrina poppigiana) terhadap aktivitas sitotoksik antikanker payudara MCF-7. Chimica et Natura Acta 3(3): 90-93.

Masyhud. 2010. Tanaman Obat Indonesia. http:// www.dephut. go.id/indexphp? =id /node/54 (06 Mei 2016). 